\title{
Otic Pit
}

National Cancer Institute

\section{Source}

National Cancer Institute. Otic Pit. NCI Thesaurus. Code C34238.

An invag ination of the otic placode during early embryonic development that will give rise

to the otic vesicle and contribute to the formation the inner ear. 